\title{
Current protocols in the generation of pluripotent stem cells: theoretical, methodological and clinical considerations
}

This article was published in the following Dove Press journal:

Stem Cells and Cloning:Advances and Applications

21 December 2009

Number of times this article has been viewed

\author{
Brad B Swelstad \\ Candace L Kerr \\ Institute for Cell Engineering, \\ Department of Obstetrics and \\ Gynecology, Johns Hopkins University, \\ Baltimore, MA, USA
}

\begin{abstract}
Pluripotent stem cells have been derived from various embryonic, fetal and adult sources. Embryonic stem cells (ESCs) and parthenogenic ESCs (pESCs) are derived from the embryo proper while embryonic germ cells (EGCs), embryonal carcinoma cells (ECCs), and germ-line stem cells (GSC) are produced from germ cells. ECCs were the first pluripotent stem cell lines established from adult testicular tumors while EGCs are generated in vitro from primordial germ cells (PGCs) isolated in late embryonic development. More recently, studies have also demonstrated the ability to produce GSCs from adult germ cells, known as spermatogonial stem cells. Unlike ECCs, the source of GSCs are normal, non-cancerous adult tissue. The study of these unique cell lines has provided information that has led to the ability to reprogram somatic cells into an ESC-like state. These cells, called induced pluripotent stem cells (iPSCs), have been derived from a number of human fetal and adult origins. With the promises pluripotent stem cells bring to cell-based therapies there remain several considerations that need to be carefully studied prior to their clinical use. Many of these issues involve understanding key factors regulating their generation, including those which define pluripotency. In this regard, the following article discusses critical aspects of pluripotent stem cell derivation and current issues about their therapeutic potential.
\end{abstract}

Keywords: pluripotency, stem cells, derivation, human

\section{Introduction}

Pluripotent stem cells have been derived from a multitude of embryonic, fetal and adult sources including somatic and germ cells (Table 1). Embryonal carcinoma cells (ECCs) were the first to be identified in the 1960 s, from the mouse ${ }^{1}$ and subsequently in human tissues. ${ }^{2}$ ECCs are pluripotent cells derived from adult testicular teratocarcinomas (or mixed germ cell tumors) from which genetic, immunological and morphological evidence suggest a primordial germ cell (PGC) origin. ${ }^{3}$ Building from these studies, pluripotent stem cells have been derived from blastocysts (embryonic stem cells, ESCs); PGCs in vitro (embryonic germ cells, EGCs) and more recently from adult germ cells (germ-line stem cells, GSCs) and unfertilized eggs (parthenogenetic pESCs). ${ }^{4}$ Of significance are gene discoveries in these stem cells that have led to the ability to produce pluripotent stem cells from differentiated adult cells. These cells, known as induced pluripotent stem cells (iPSCs), have been accomplished by genetic and biochemical engineering of adult and progenitor cells with pluripotent regulators. This review will summarize current issues regarding the derivation and potential clinical applications of pluripotent cells, with a focus on human-derived stem cells (Figure 1).
Correspondence: Candace L Kerr Institute for Cell Engineering, Department of Obstetrics and Gynecology, Johns Hopkins University 733 N. Broadway, Broadway Research Building, Suite 769, Baltimore, Maryland 21205, USA

Tel +l 4I0 6I4 3444

$\mathrm{Fax}+\mathrm{I} 4109557427$

Email ckerr@jhmi.edu 
Table I Types of pluripotent stem cell lines

\begin{tabular}{ll}
\hline & Human \\
\hline Pluripotent stem cell & Source \\
Embryonic stem cells & 32-cell blastocysts 8-cell morula \\
Epiblast stem cells & Epiblast \\
Induced pluripotent stem cells & Unipotent fetal and adult cells \\
Embryonal carcinoma cells & Teratocarcinoma \\
Parthenogenic stem cells & Chemical-activated unfertilized egg \\
Germline stem cells & Spermatogonia stem cells from fetal \\
& and adult males \\
Embryonic germ cells & Primordial germ cells \\
& Mouse only \\
SCNT-derived ESCs & Mouse blastocysts as a result of \\
& inserting the nucleus of an adult \\
& mouse cell into an unfertilized egg \\
\hline
\end{tabular}

Abbreviations: ESC, embryonic stem cells; SNC, somatic cell nuclear transfer.

These unique cell lines share the general properties of pluripotent stem cells including unlimited self-renewal and the ability to give rise to derivatives of all three embryonic germ layers. Pluripotency of these cell types is demonstrated experimentally by producing cell types representing all three germ layers either spontaneously during embryoid body formation, using directed differentiation protocols in culture or in teratomas after injection into adult mice. ESCs, EGCs and iPSCs have also demonstrated the ability to produce representatives of the germ cell lineage. ${ }^{5-20}$ The most stringent test for pluripotency involves the ability of these cells to contribute to the development of the embryo proper either partially, in chimeric mice or solely by tetraploid complementation. While most pluripotent cell types have demonstrated their contributions in chimeric mice, ESCs and now more recently, iPSCs have also proven the ability to produce viable offspring through tetraploid complementation. ${ }^{21,22}$

\section{Methodology \\ Embryonic stem cells}

The derivation and maintenance of sustainable human ESCs were first performed in 1998 by James Thomson when his team cultured the inner cell mass of developing blastocysts (embryo proper) from donated embryos received from in vitro fertilization (IVF) programs. ${ }^{23}$ During this same time John Gearhart derived EGCs from cultured PGCs of the genital ridge. ${ }^{24}$ Both research teams developed techniques learned from several decades of prior animal studies deriving pluripotent cell lines from mouse blastocysts. ${ }^{25,26}$ Since this time, rapid progress has been achieved in improving culture conditions as more lines are developed. These improvements have primarily addressed two important issues with ESC derivation, the ability to acquire viable starting material and for clinical purposes to derive them under xeno-free conditions. This section will focus on recent updates and novel approaches for deriving and maintaining ESCs. Importantly, advances in ESC derivation will be critical given the shift in the political climate toward expanding stem cell research.

ESCs are isolated from the inner cell mass of 5- to 7-dayold blastocysts and cultured with mitotically-inactivated fibroblast cells. An in depth review of embryo-derived stem cells has been undertaken by Smith, ${ }^{27}$ and comprehensive reviews with methodologies can be found in several books. ${ }^{28-30}$ Successful derivation of ESCs is limited by the quality and quantity of the inner cell mass obtained. ${ }^{31}$ As most lines have been developed from blastocysts for IVF purposes that would have otherwise been discarded, their quality is less than optimal for implantation. Recently, Daley and colleagues have reported an improved method for deriving ESCs from discarded poor-quality embryos from infertility centers. ${ }^{32}$ This study utilized hypoxic conditions based on previous studies which show hypoxia was beneficial for preimplantation development, ESC cloning and maintaining pluripotency in culture. ${ }^{33-35}$ However, the researchers were careful to state that their experiments were not designed to conclude whether hypoxia was beneficial for derivation. More recently, Yamanaka and colleagues have also reported 40-fold higher efficiency rates in iPSC production under hypoxic conditions compared to controls. ${ }^{36}$ Another issue raised by Lerou and colleagues ${ }^{37}$ was eliminating the standard immunosurgery and other manipulations normally used to remove the inner cell mass from the blastocysts. As these structures are usually disrupted in poor quality embryos this step would alleviate the stress these procedures apply to the cells. Using this combined strategy their results demonstrated $4 \%$ to $6 \%$ derivation efficiencies similar to lines derived by frozen embryos. ${ }^{38}$

Optimizing derivation of human ESC lines under animal free conditions is continually evolving as it remains a fundamental concern for their use in cell based therapies. Several reports have demonstrated the ability to derive human ESCs under serum-free and feeder-free conditions but the stability of these cells over long term culture is uncertain. ${ }^{39,40}$ Importantly, it will remain to be seen if the approaches that are now employed to enhance iPSC derivation can in fact also enhance the efficiency of human ESC derivation under these conditions as well. For instance, 


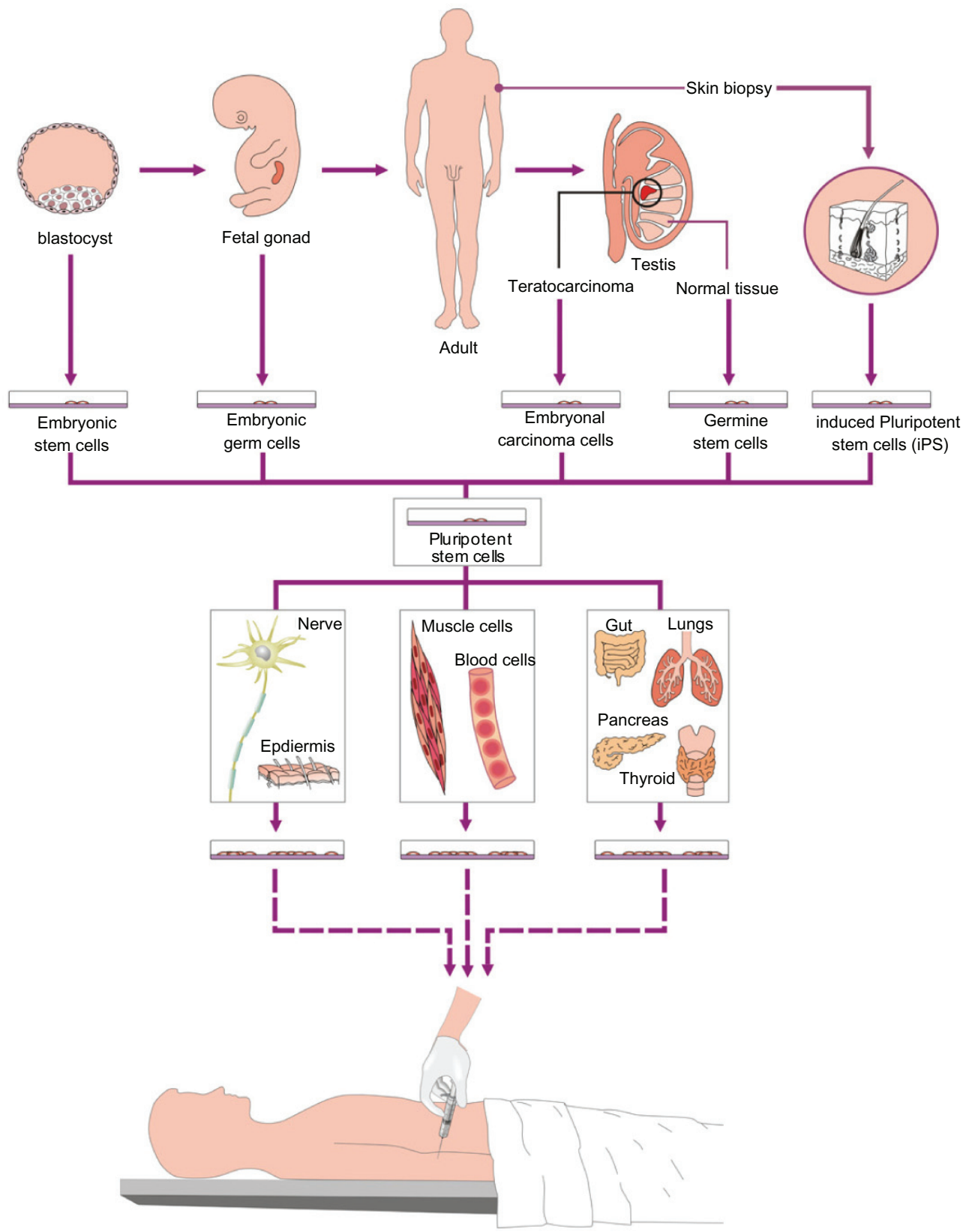

Figure I Human pluripotent stem cells include embryonic stem cells cultured from cells of the inner cell mass of normal or parthenogenetic blastocysts, embryonic germ cells generated from primordial germ cells in late embryonic development, embryonal carcinoma cells isolated from adult teratocarcinomas, germline stem cells derived from spermatogonia, and induced pluripotent stem cells generated by reprogramming differentiated adult cells. Pluripotent stem cells exhibit the potential to produce all cell types of the body.Thus, directed differentiation of these cells holds promise for treating a wide variety of diseases and injuries.

a recent study demonstrated that epigenetic modifying reagents like 5-aza-2'-deoxycytidine (AZA) and trichostatin A (TSA) significantly improve efficiency rates in mouse ESC derivation (40\% when both AZA and TSA are added compared to $5 \%$ in controls). ${ }^{41}$ In the mouse, epigenetic modifying reagents have been shown to dedifferentiate ESCs after embryoid formation and prevent ESC differentiation. ${ }^{42,43}$ These studies exemplify how defining pluripotency and the factors that regulate self-renewal will be critical for improving pluripotent stem cell derivation as well as for the development of new stem cell types.

\section{Induced pluripotent stem cells}

Since the development of the first iPSCs almost 3 years ago, multiple laboratories have reported on the ability to derive iPSCs in mouse, human, rat and monkey cells by genetic and/or chemical manipulation using a small set of transcription factors and in some cases, chemical modifiers. ${ }^{44}$ Unlike traditional 
methods which utilize viral integration to introduce gene expression, current iPSC strategies focus on reprogramming cells more suitable for clinical applications. ${ }^{45}$ These methods include transduction with proteins alone (protein transduction), utilizing small molecules that are able to facilitate expression of reprogramming factors, and by employing nonintegrating vectors that transiently express reprogramming factors. Most studies involve the exogenous expression of known genes regulating pluripotency, such as Oct4, Nanog, and Sox2 (Lin28 and Fbx12) in addition to oncogenic factors such as c-Myc and Klf4. ${ }^{46-48}$ In every case, the combination of these factors expressed in more differentiated cell types successfully produced ESC-like colonies. These studies demonstrate that Oct4 and Sox2 are critical for reprogramming cells, while c-Myc and Klf4 expression, though not critical for transformation, does significantly increase reprogramming efficiency. In three cases, iPSCs were generated without the use of an oncogenic factor. In the first study by Thompson and colleagues, they successfully reprogrammed human fetal and neonatal fibroblasts using Lin28 and Nanog in place of Myc and Klf4. The ability to eliminate oncogenic factors like Myc and Klf4 may be attributable to differences in plasticity of reprogramming less and more differentiated cells. ${ }^{49,50}$ In the remaining two studies, Oct4 and Sox 2 were utilized along with either SV40 large T antigen to reprogram human fibroblasts or with a histone deacetylase inhibitor to reprogram mouse fibroblasts. $^{49,50}$

Genetic integration using either a lenti- or retrovirus has been the most common method for iPSC production. One problem with generating iPSCs using lentiviral integration occurs when the inserted pluripotent genes are not silenced over time, thereby preventing differentiation of the cells for clinical application. ${ }^{50}$ For this reason, retroviruses have been employed using a similar strategy. With retroviruses, gene silencing usually occurs a few weeks after host cell integration. However, compared to lentiviruses, retroviruses exhibit lower transduction efficiencies since these viruses specifically target replicating cells and in some cases, silencing does not occur. ${ }^{51}$

One main issue in iPSC induction is avoiding factors which promote tumorigenesis. To circumvent the issue of oncogenic transgene integration into the host genome, several methods are used including adenoviral transduction, transient transfection, piggyBac transposon gene-delivery system, and various chemical reagents including the direct delivery of the reprogramming proteins themselves. ${ }^{51-55}$ The minimal set of transcription factors required to induce reprogramming is constantly being refined, as well as the application of chemical inhibitors and signaling molecules. Chemical inhibitors involved in DNA methylation, histone methylation, and acetylation not only improve reprogramming efficiencies and kinetics, but also prevent the use of additional reprogramming factors. For instance, chemical inhibitors such as AZA, valproic acid (VPA), and BIX-01294 (BIX), involved in epigenetic processes have been demonstrated to improve reprogramming when combined with conventional reprogramming factors, such as Oct4 and Nanog. ${ }^{49,56-60}$ Other molecules such as Wnt3a, $2 \mathrm{i}$, and A-83-01, have also been employed to target specific pathways which appear to enhance the transition to fully programmed iPSCs. ${ }^{58-60}$ Nonetheless, it still remains a challenge to reprogram somatic cells by chemical treatment alone. Another critical issue in iPSC derivation is the safety of small molecules used to generate therapeutically relevant iPSCs. For example, some of these chemicals not only exert known localized changes in cells, but they also promote global modifications which will most likely result in genetic aberrations and/or dysregulation of genes. A specific example of this concept is AZA, which is known to induce DNA damage. ${ }^{61}$

Independent of the iPSC derivation method used, iPSC-like colonies appear to form 1 to 4 weeks after transfection. This time depends, in part, on the differentiated state of the host cells with less differentiated cells requiring a shorter time to form colonies. These colonies are then selected for clonal propagation based on morphology. Pluripotent expression patterns normally take an additional 3 to 4 weeks to develop depending on the cells and methods involved. At this point, colonies should exhibit greater than $70 \%$ to $90 \%$ OCT $^{+}$ cells. Many colonies will never completely transform into pluripotent stem cells so it is very important to select and purify cells based on pluripotent cell surface markers. ${ }^{62}$ It is the authors' experience that TRA-1-60 or TRA-1-81 appear to be more effective than SSEA4 for identifying pluripotent human cells.

Another issue in iPSC induction is the low rate of transformation of the transfected host cells. With the use of transgene expression alone $0.001 \%$ to $0.1 \%$ efficiencies have been reported, but with the addition of other "enhancing" molecules or hypoxic cell culture conditions, ${ }^{36}$ this rate is reported to be at most 3\% in human cells and $10 \%$ in mouse cells. ${ }^{46,49}$ It also appears that higher efficiency rates are correlated with cells from earlier developmental tissue. For instance, work from our laboratory has shown efficiencies of $\sim 2 \%$ with only the addition of two genes when applying iPSC technology to human PGCs (Figure 2). Pera and 


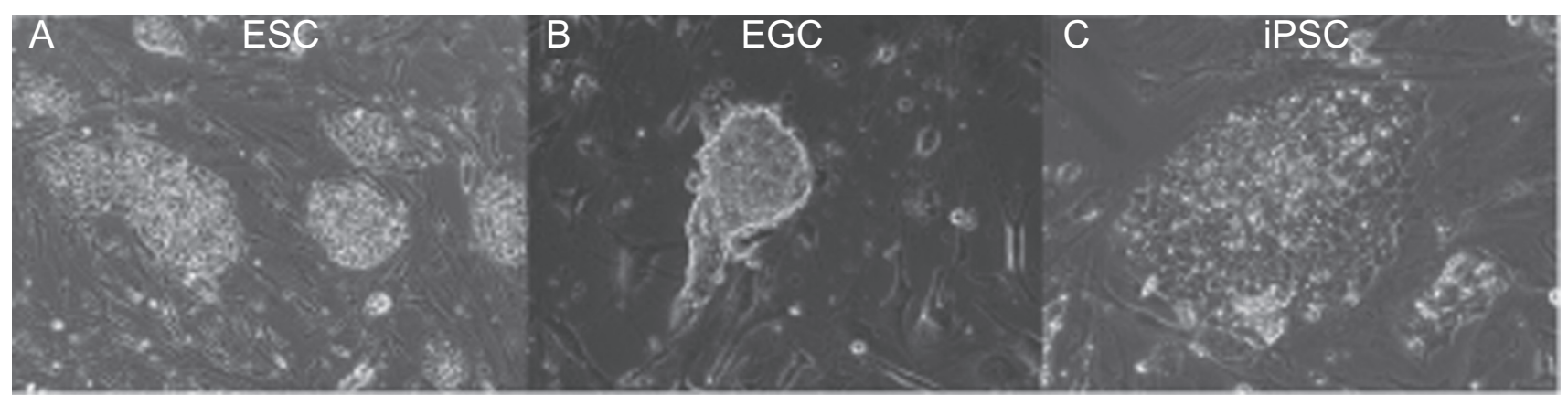

Figure 2 Pluripotent stem cell derivation produce colonies similar in morphology and culturing conditions. A) ESC colonies. B) EGC and C) PGC-derived iPSC colony. Abbreviations: ESC, embryonic stem cells; EGCs, embryonic germ cells; PGC, primordial germ cells; iPSC, induced pluripotent stem cells.

colleagues also demonstrated that a subpopulation of human adult fibroblasts expressing the pluripotency marker stage specific embryonic antigen 3 (SSEA3) were the source of iPSC colonies after transduction with Oct4, Sox2, Klf4 and cMyc. ${ }^{63}$ In this report, the efficiency of iPSC derivation was increased by 8 -fold while no colonies were generated from SSEA3 negative cells. This evidence lends support to one of two models recently proposed by Yamanaka to explain the low efficiency and partial nature of iPSC generations. Here, the possibility that only SSEA3+ cells generate colonies supports that only an "elite" subset of cells are competent for reprogramming. ${ }^{64}$ Alternatively, Yamanaka also proposes a stochastic model in which most, if not all, differentiated cells have the potential to become iPSCs. His laboratory and others provide evidence for this model by demonstrating that iPSC formation is impaired by general mechanisms involved in regulating senescence including the p53 and p21 pathways. ${ }^{65,66}$ Thus, while studies generating iPSCs provide hope for reprogramming adult cells for therapeutic uses, iPSC research also emphasizes the need to continue finding mechanisms that regulate pluripotency and cellular reprogramming. For this purpose, future studies identifying the factors that regulate cellular reprogramming of lineagerestricted cells will be critical.

Lineage reprogramming has been shown to occur naturally in lower vertebrates by several different strategies including dedifferentiation ${ }^{62}$ and transdifferentiation. ${ }^{67}$ In fact, transdifferentiation in mammalian cells has been recently highlighted by two studies. Graf and colleagues have shown that lineage switching is possible in the hematopoietic system whereby the overexpression of $\mathrm{C} / \mathrm{EBP} \alpha$ and $\beta$ is sufficient to reprogram B lymphocytes into macrophages. Melton and colleagues have also demonstrated lineage switching by directly converting mature pancreatic exocrine cells to endocrine $\beta$ cells in adult mice. ${ }^{68,69}$ In this study a genome-wide expression analysis of $>1100$ transcription factors from the developing pancreas was employed which revealed specific expression in distinct progenitor cells. Using knockout studies to pinpoint genes required for $\beta$ cell fate specification, they were able to identify just three factors that together reprogrammed adult exocrine cells into $\beta$ cells. These studies illustrate the significance of elucidating the molecular machinery that underlies reprogramming which can in turn be utilized to develop strategies to reprogram cell fate that do not require the pluripotent state.

\section{Embryonic germ cells}

Primordial germ cells are the progenitor cells of the germ cell lineage, which are the sole source of gametes in the adult. During human development, 50 to 100 PGCs are first distinguishable at $\sim 22$ days in the endoderm of the dorsal wall of the yolk sac, near the allantois and in the mesenchyme of the stalk. From there, they proceed to migrate through the hindgut during the fourth week and dorsal mesentery in the fifth week to reach the genital ridge. ${ }^{70-72}$ By the end of the fifth week or early in the sixth week, $\sim 1000$ PGCs begin to actively migrate from the dorsal mesentery to the genital ridge. ${ }^{73-75}$ At this time, in the female, premeiotic PGCs begin extensive mitotic expansion until they arrest in prophase of meiosis I beginning around week 10 in gestation. ${ }^{70}$ In contrast, at 8 weeks male PGCs begin extensive mitotic expansion and then arrest around 10 weeks gestation. ${ }^{73,74,76-78}$ To derive human EGCs, PGCs are isolated from the fetal gonad between 5 and 10 weeks' gestation. This time period coincides with peak PGC proliferation and encompasses the period in which the gonad undergoes sexual dimorphism into either an ovary or testis starting in the 7 th week. ${ }^{79}$ PGCs are unipotent in that they are lineagerestricted to become germ cells, do not exhibit self renewal and do not survive past one week under standard tissue 
culture conditions. ${ }^{80}$ The derivation of EGCs from human tissue has been performed by adapting methods based in part from the original EGC derivation in the mouse. Unlike other pluripotent stem cells which are primarily derived on primary mouse embryonic feeder cells (MEF), EGCs have been mainly derived using the transformed mouse embryonic fibroblast line, Sandoz Thioguanine- and Ouabain-resistant mouse fibroblasts (STO). A few reports deriving mouse and recently one involving human PGCs has successfully utilized MEFs for EGC derivation. ${ }^{81-84}$

In most studies, EGC growth media has consisted of serum as first reported for human ESC derivation. ${ }^{23}$ However, a recent report suggests that $\mathrm{MEF}$ with serum replacement are more efficient for human EGC derivation. ${ }^{81}$ These results highlight that more research in this area is needed to improve EGC derivation. For instance, deriving EGCs is a unique process when compared to deriving other ESCs by the addition of several different factors. Forskolin is one such pharmacological agent which raises intracellular cAMP levels and has been shown to stimulate mitosis in PGC cultures. ${ }^{80}$ Forskolin has been uniquely employed in EGC derivation to increase derivation efficiency, however, it is not required. Derivation of human EGCs also relies on leukemia inhibitor factor (LIF). LIF was originally known for its inhibitory role in liver cell differentiation $^{85}$ and later employed for the derivation of mouse embryonic stem cells (mESC) where it signals via the LIF receptor (LIFR), gp130 and intracellular stat $3 b$ to maintain mESC pluripotency. ${ }^{86}$ However, activation of this pathway does not maintain self-renewal of human ESCs, but is required for human and mouse EGC culture. Another growth factor which may be critical for EGC derivation is stem cell factor (SCF), also known as c-kit ligand. Used for mouse EGC derivation, this factor is well known for its role in $\mathrm{mPGC}$ proliferation and survival and has been attributable to the reduced ability of MEFs when compared to STO for culturing mPGCs. ${ }^{85}$ Although our laboratory has not seen an effect of adding SCF in our human EGC cultures, we have shown a positive correlation in PGC proliferation and survival in cultures with subcloned STO feeder cells expressing increased concentrations of transmembrane SCF. ${ }^{87}$ Finally, EGC derivation like all other pluripotent stem cells relies on fibroblast growth factor (FGF2) for proliferation and survival. FGF2 functions as a potent mitogen in many cell types, and was also the determining factor which led to the first EGC derivation from mice. ${ }^{88-90}$

In the first week, most human PGC cultures do not produce visible EGC colonies. Staining for tissue non-specific alkaline phosphatase (TnAP) activity demonstrates the presence of solitary PGCs with either stationary or migratory morphology. After 2 to 3 weeks, large and recognizable EGC colonies develop at approximately $10 \%$ to $20 \%$ efficiency rates. Compared to other pluripotent stem cells, EGCs are challenging to maintain due to the difficulty in disaggregating colonies. This issue together with problems in obtaining PGCs significantly hampers research in this area.

\section{Germ-line stem cells}

Recent studies have shown that pluripotent stem cells can also be produced from germ cells isolated further along in male development. ${ }^{91-93}$ These cells, known as germ-line stem cells (GSCs), were first generated from mouse spermatogonia, and last year, the first study was reported deriving GSCs from testicular biopsies of men. ${ }^{91-93}$ Spermatogonia stem cells (SSCs) of the male germ line are present at birth. They develop from PGCs in the fetal gonad and consist of multiple subpopulations that either self renew or continue the differentiation process leading to sperm development. Although GSCs derived from the neonate mouse produced teratomas, cells initially reported from the adult testis did not, suggesting that they were multipotent. ${ }^{94,95}$ However, Scholer and colleagues using a different method derived GSCs from adult mice which demonstrated teratoma and chimera formation, including germ cell contribution and transmission. ${ }^{96}$ Similar experiments have also been performed on human adult testicular biopsies which in one study produced GSCs capable of teratoma formation. ${ }^{94,97}$ As with any human germ cell line, these cells cannot be utilized for chimera testing.

In both the mouse and human studies, the ability to generate fully reprogrammed GSCs that can form teratomas and contribute to chimeras appears to be dependent on the method of cell selection and possibly the growth factors employed. For instance, these studies utilized different cell-surface markers including CD49f, CD90, GDNFR $\alpha 1$, and CD133 in combination with various cell culture matrices like collagen and laminin, to select the "appropriate" spermatogonial subpopulation.

The success of deriving GSCs is attributable to a long history of studying SSCs in culture. ${ }^{98-100}$ Interesting comparisons can be made between GSC culture conditions and culture conditions used to produce other pluripotent stem cells. For instance, like EGCs, several lines of evidence suggest that GSCs may require LIF for complete reprogramming. This is supported by Conrad and colleagues who demonstrated by testing various conditions with and without LIF, that LIF alone was sufficient to produce viable GSC lines capable of forming teratomas. His study also 
noted that the addition of fibroblast growth factor 2 (FGF2) or glial-derived neurotrophic factor (GDNF) did not increase the efficiency rate. ${ }^{94}$ In contrast, Kossack and colleagues attempted to generated human GSCs without the use of LIF and were unable to demonstrate teratoma formation. ${ }^{97}$ In addition, culturing cells over a longer period of time in the presence of LIF under ESC culture was attributed to the generation of mouse GSCs which not only formed teratomas, but also produced chimeras with germ-line transmission. ${ }^{96}$ Interestingly though, unlike EGCs, human GSC generation does not appear to require FGF2 or GDNF which have been shown previously to support SSC survival in culture.

One benefit of GSCs it that they provide an adult source for pluripotent stem cells without the complications of reprogramming. Yet further analysis and functional validation in animal studies are required to evaluate their potential for clinical applications. Two primary concerns about the use of GSCs for clinical applications include their uniparental epigenetic imprints and the potential availability they may have for only male patients.

\section{Parthenogenetic stem cells}

Parthenogenesis is the development of a diploid embryo from a female gamete without contributions from a male. This process occurs naturally in some invertebrate and vertebrate species (such as reptiles, fish), but is very rare in mammals. Parthenogenetic activation can also be induced experimentally using chemicals to mimic sperminduced $\mathrm{Ca}^{2+}$ oscillations (such as alcohol, ionomycin, or cycloheximide) or by physical stimulation including mechanical stimulation, cold temperatures and electrical shock. ${ }^{101-103}$ After activation, exposure to cytoskeletal inhibitors (such as 6-dimethylaminopurine) prevent the extrusion of the second polar body creating a diploid parthenote. In mammals, parthenogenetic embryos are unable to thrive beyond the early postimplantation stage, largely because of the lack of paternally expressed imprinted genes required for the normal development of extra embryonic tissues. ${ }^{104,105}$ In fact, Kono and colleagues have demonstrated the ability to produce the birth of live parthenogenetic mice which were able to produce offspring when the appropriate imprinting of key genes were expressed. ${ }^{106,107}$ In humans, this concept is also demonstrated in a single case report of spontaneous parthenogenetic chimerism in which the patient survived with a mixed makeup of normal and parthenogenetic cells. ${ }^{108}$

The first report of the intentional creation of human patient specific pESC lines was published by Pryzhkova and colleagues. ${ }^{109}$ These lines possessed all of the typical characteristics of human ESC lines generated from IVF embryos. This includes pluripotent marker expression (summarized in Table 2), the ability to differentiate into cellular derivatives of all three germ layers in vitro and the ability to form teratomas in immuno-deficient mice (reviewed in). ${ }^{110}$ Although chimeric studies cannot be applied to human pESCs, mouse pESCs have contributed to adult tissue in chimeras including germ-line transmission. ${ }^{111-113}$ Human pESCs lines have also been generated by other laboratories. ${ }^{114,115}$ In fact, the erroneous report by Hwang and colleagues declaring the first successful derivation of a human somatic cell nuclear transfer (SCNT) ESC-line was later identified by Daley and colleagues to be pESCs which contained genetic material solely from the oocyte donor. ${ }^{16,117}$ Together these studies have shown that $\mathrm{pESCs}$ can be derived successfully at relatively high efficiency rates, $\sim 10 \%$ to $16 \%$ when compared with other stem cells. ${ }^{102,114,115,117,118}$

From work in mice, it was originally thought that human pESCs would also be for the most part genetically homozygous. ${ }^{119}$ This is critical from a clinical standpoint in terms of minimizing the risk of immunological rejection in patients. However, two landmark reports on this issue demonstrated several human pESC lines that were heterozygous at several loci which resulted from genetic recombination events during oocyte maturation. Importantly, loci included the major histocompatibility complex (MHC) which plays a defining role in autoimmunity. ${ }^{109,114}$ This issue was resolved by two groups who demonstrated methods to generate HLA-homozygous pESC lines by pre-selecting an HLA-homozygous egg donor ${ }^{120}$ or by generating haploid parthenogenetic embryos. ${ }^{115,120}$ These cells are produced by eliminating the cytoskeletal inhibitor step which permits the extrusion of the second polar body after oocyte activation. ${ }^{120}$

Table 2 Pluripotent stem cell markers

\begin{tabular}{lllllll}
\hline Marker & ESC & GSC & EGC & pESC & iPSC & ECC \\
\hline Tra-I-60,8I & + & + & + &,++ & + & + \\
SSEA3 & + & + & + & + & + & + \\
SSEA4 & + & + & + & + & + & + \\
SSEAI & - & - & + & - & - & - \\
TnAP & + & + & + & + & + & + \\
Telomerase & + & + & + & + & + & + \\
Oct4 & + & + & + & + & + & + \\
Nanog & + & - & + & + & + & + \\
Sox2 & + & + & low & + & + & + \\
\hline
\end{tabular}

Abbreviations: ECC, embryonal carcinoma cells; EGC, embryonic germ cells; ESC, embryonic stem cells; pESC, parthenogenic ESC; GSC, germ-line stem cells; iPSC, induced pluripotent stem cells. 
In general, pESC derivation mimics those of ESCs in terms of blastocyst isolation and cell culture. Oocytes are collected from donors after hormonal stimulation for in vitro fertilization (IVF) purposes and then subjected to electric stimulation or as Pryzhkova and colleagues have shown, chemical induction alone with ionophore, for egg activation followed by kinase inhibitor 6-dimethylaminopurine (6-DMAP) to prevent the extrusion of the second polar body (this step eliminated for homozygous lines). ${ }^{102,109} \mathrm{After}$ activation, embryos are cultured and the inner cell mass (ICM) is isolated from days 5-6 blastocysts. Like ESCs, derivation requires either human or mouse fibroblasts as a feeder layer. Growth media and serum requirements for $\mathrm{pESC}$ derivation are also similar to those used for ESC derivation which include knockout serum replacement (Invitrogen) or human serum. While all studies utilize FGF2 most, but not all, used LIF demonstrating LIF is not critical for deriving pESCs (pers comm, Dr Marina Pryzhkova). ${ }^{115}$

Another possible source for human pESCs has been demonstrated in reproductively incompetent oocytes, including those that are immature, failed or abnormally fertilized from IVF. These cells are normally discarded during IVF and so alleviate some of the ethical concerns that surround using normal embryos. The process of IVF or intracytoplasmic sperm injection (ICSI) can sometimes produce aneuploid embryos with none or multiple pronuclei. ${ }^{121}$ In 2004, Suss-Toby and colleagues reported the generation of a human ESC line from a mononuclear zygote following ICSI, which demonstrated normal diploid female karyotype $(46, \mathrm{XX})$ and corresponding ESC characteristics. ${ }^{121}$ These authors suggest, that mononuclear zygotes can develop into normal blastocysts after sperm penetration as a result of asynchronous formation of pronuclei. Although, this study did not determine the parthenogenetic origin of the ESC line, others have now shown that mononuclear zygotes discarded from IVF can be an additional source for creating human pESCs. Of importance, these parthenogenetic lines expressed all of the properties of a normal euploid hESC line. ${ }^{115,118,122}$

One important factor in the therapeutic application of pESCs is that currently human pESCs have only been derived from fresh oocytes making this stem cell limited to women who are able to donate eggs. However, if human pESCs could be derived from cryopreserved oocytes this would provide the opportunity to treat women with decreased ovarian reserve and women needing chemotherapy. Two recent studies show great promise in this area. For example, mouse pESC lines that have been derived from cryopreserved ovaries, express ESC-specific markers and differentiate into embryoid bodies in vitro and teratomas in vivo. ${ }^{123}$ Another study has also demonstrated the ability to produce parthenogenetic human blastocysts from cryopreserved oocytes at high efficiency rates. ${ }^{124}$ Together these studies provide promise for cryopreserved eggs in the future as a potential source for pESCs.

Unlike work done in ESCs and EGCs, few studies have explored the clinical application of pESCs using transplant models. ${ }^{125}$ For instance, one study has shown the stable and functional hematopoietic engraftment of mouse pESCs derived from uniparental genomes. ${ }^{126}$ Another study demonstrated the ability of rabbit pESCs to differentiate into myogenic, osteogenic, adipogenic, and endothelial lineages. These cells were injected into a chemically induced injured tibialis muscle of nude mice, where they were able to integrate and form muscle- and bone-like tissues. ${ }^{127}$ In addition to these studies, pESCs from nonhuman primates have also been derived that could differentiate into dopamine neurons that restore function in a rat model of Parkinson's disease. ${ }^{128}$

\section{Clinical considerations}

Given their properties of unlimited self renewal and differentiating potential, pluripotent stem cells hold the promise of providing sufficient numbers of differentiated cells that could potentially be used to treat a wide variety of human conditions, including heart disease, diabetes, and many neurological disorders. However, it is unknown which source of pluripotent stem cells will provide the best therapy for any given disease or affliction. In fact, it seems more reasonable given the uniqueness of different pluripotent stem cells that there will not be only one given stem cell line or approach that provides the single resolution for the diverse needs across all cell-based therapies. Most importantly, the ideal candidate must be easily and reproducibly cultured and manipulated so that the stem cells possess the necessary characteristics for successful differentiation, transplantation and engraftment. This includes taking steps to prevent unregulated proliferation, unwanted cell migration from the lesion site, incorrect differentiation, and poor functioning of transplanted cells.

Ethical and scientific hurdles remain when using pluripotent stem cells in cell-based therapy. For instance, the ethical issues surrounding the use of embryonic and fetal sources for many of these lines present a challenge. In this respect, iPSCs from adult tissues are less controversial and provide an avenue for producing patient-specific cell lines which would eliminate complications involving allograft rejection. ${ }^{46,129-131}$ However, one of the main obstacles for utilizing these cells is the use of oncogenic factors or vectors 
which may cause tumorigenesis. In fact, all of the iPSCs reported to date require an oncogenic factor to produce lines from adult tissue at a notable efficiency. ${ }^{4}$ Several studies have reported on karyotypic abnormalities which develop in iPSC lines. ${ }^{50,132}$ For instance, Cheng and colleagues found that utilizing the SV40 large T antigen (Simian Vacuolating Virus $40 \mathrm{TAg}$ ) to increase transduction efficiency, led to the majority of iPSC lines with abnormal karyotypes. This is not surprising given that the large $\mathrm{T}$ antigen is an oncogene associated with the transformation in a variety of cell types. ${ }^{133}$ Another problem facing iPSC technology is poor efficiency with reported induction rates of only $0.001 \%$ to $10 \%$ from transfected cells. These rates strongly suggest the involvement of other factors that are critical to regulate reprogramming.

Several reports of the therapeutic use of human pluripotent stem cell-derived cells have been reported across animal models representing a variety of treatable diseases and injuries. First clinical reports were shown in neural-derived cells from human ECCs and EGCs. ${ }^{130}$ These studies included the use of EGC-derived neural stem cells in animal models of stroke and motor neuron injury. In a rat model of spinal cord injury, transplanted cells appeared to promote partial recovery of the spine by protecting motor neuron death. ${ }^{134}$ However, in a mouse excitotoxic brain damage model, EGC-derived cells migrated away from the lesion sight and toward damaged areas within the striatum, hippocampus, thalamus, and white matter tracts. ${ }^{135}$ Models other than neuronal differentiation have also been employed using EGCs-derived cells. For example, EGC-derived cells have also been shown to successfully replace certain bladder defects induced in rats. ${ }^{136}$

Reports using animal models have also shown the therapeutic use of human ESC-derived cells. These have included a gamut of cell types including insulin secreting islets, retinal cells, liver, chondrocytes, cardiomyocytes, and cells of the neural lineage. ${ }^{129,137-139}$ Studies have shown that cells derived from human ESCs led to improvements in animal models of osteochondral defects, ${ }^{140,141}$ diabetes, ${ }^{142}$ heart ischemia, ${ }^{143-146}$ Parkinson's, ${ }^{147,148}$ spinal cord injury, ${ }^{134,149-152}$ stroke, ${ }^{153-156}$ liver disease, ${ }^{157}$ macular degeneration ${ }^{158}$ and multiple sclerosis. ${ }^{159,160}$ In fact, work led by Keirstead and colleagues involving ESC-derived glial cells in rat spinal cord injury models almost led to the first FDA-approved human clinical trials involving ESC-derived progenitors in the summer of 2009. ${ }^{161}$ This trial sponsored by Geron Corp (Menlo Park, CA, USA), involved injecting human ESC-derived oligodendrocyte progenitors into patients with severe spinal cord injury, but was halted when benign appearing cysts began developing in some of the animal trials. Other clinical trials have also been reported in the near future using ESC-derived retinal pigmented epithelium for macular degeneration and ESC-derived $\beta$ islet cells for the treatment of diabetes. ${ }^{158,162}$

Despite there being no current reports using human iPSC-derived cells, studies have begun to show the utility of mouse iPSCs in animal transplant models. Several of these models involve neural and cardiac afflictions. For instance, one study has shown that mouse iPSC-derived neurons have the ability to not only integrate themselves into fetal brains, but also improve symptoms of rats with Parkinson's disease. ${ }^{163}$ Another study implicated iPSC-derived progenitors in the treatment of acute myocardial infarction. ${ }^{164}$ With the exciting promise of iPSC-based therapies studies have begun demonstrating the ability to derive iPSCs from patients with a specific disease. The first report of patient-specific lines were those developed by Cheng and colleagues from patients with sickle cell anemia. ${ }^{50}$ Since then, human iPSCs have also been generated from skin biopsies of patients with spinal muscular atrophy, amyotrophic lateral sclerosis and familial dysautonomia which demonstrated the ability to differentiate into motor neurons. ${ }^{165-167}$ Likewise, iPSCs from patients with type 1 diabetes have been derived that could differentiate into insulin-producing cells. ${ }^{168}$ Proof of iPSC potential for patient-specific treatments comes from a landmark paper describing the treatment of a humanized sickle cell anemia mouse model with iPSCs generated from autologous skin. ${ }^{169}$ In this study, Hanna and colleagues derived an iPSC line from a transgenic mouse expressing a human sickle cell gene, corrected the mutant $\alpha$-globin gene producing this disease and then showed that the differentiated cells from the corrected iPSC line were able to treat the disease when injected back into the knock-in mice. More recently, iPSCs have also been generated from $\beta$-thalassemia patients. ${ }^{170}$

Two primary concerns for the use of pluripotent stem cell-derived tissue are host-graft rejection and tumor formation. Graft-versus-host rejection is a critical factor in nonpatient-derived pluripotent stem cells. Therefore, it is critical to have stem cell-derived transplants that are a similar match to the histocompatibility complex of the patient in order to prevent complications associated with long-term immune suppression. ${ }^{171}$ This is especially pertinent to stem cell-based therapies where cells are integrated into host tissue and as such cannot be surgically removed. However, one solution is to generate a registry of HLA-typed pluripotent stem cell lines from various ethnic groups. The possibility to create a bank of HLA-homozygous 
stem cell lines, which could be MHC, matched for the majority of human population, is dependent on determining a realistic number that would satisfy a sizable population. However, the number of actual ESC lines that would be needed for a perfect tissue match is still under considerable debate, with estimates by different groups ranging from the hundreds to the thousands. ${ }^{171,172}$ The considerable range in these studies can be in part contributed to the genetic diversity of the population as well as the criteria set forth for HLA mismatch. In contrast, a few papers have also estimated smaller numbers for $\mathrm{pESC}$ lines. These studies estimate that 10 to 70 lines of homozygous human pESC lines would be needed to cover the majority of the Japanese, UK and US populations. ${ }^{172-174}$

Several issues about pluripotent stem cells have raised concerns on their potential for tumor formation in clinical applications. First, all pluripotent stem cell lines have the propensity to become chromosomally abnormal over longterm culture, a characteristic feature of carcinogenesis. In fact, ESCs and iPSCs share similarities with the pluripotent cancer stem cells, ECCs, including abnormalities in chromosomes 12,17 , and $\mathrm{X}$ all of which are implemented in generating teratocarcinomas. ${ }^{47,175-178}$ Using array-based comparative genomic hybridization ( $\mathrm{aCGH})$, a recent report comparing 17 human ESC lines also identified amplification at 20q11.21 and a derivative of chromosome $18 .{ }^{179}$ It will remain to be seen if the application of this relatively new technology for stem cell purposes will identify more abnormalities missed by chromosomal banding techniques. Secondly, there is always the possibility that some stem cells remain pluripotent even after long-term culturing conditions which promote differentiation. Thus, efficient differentiation protocols along with rigid cell selection must be available to provide pure populations prior to transplantation.

Nevertheless, there is a risk that less differentiated progenitors derived from pluripotent cells may also generate tumor formation. This can be caused by either the innate properties of the cells themselves or by the host environment. For example, it has been shown that leukemias develop more frequently when hematopoietic stem cells are derived from umbilical cord blood as compared to bone marrow or blood suggesting that immature cells may carry higher risks for malignancy. ${ }^{180}$ There are also numerous examples of bone marrow transplantation where donor-derived human bone marrow cells contributed to solid organ cancers. ${ }^{181-183}$ Whether these bone-marrow-derived cells are responsible for tumor formation or contributed to a microenvironment that supports tumor growth is not clear. ${ }^{47,184,185}$
Studies have suggested that the frequent presence of fetalderived cells in the stroma of malignant breast cancer tumors associated with pregnancy and in some cervical cancers may play a role in their cancer progression. ${ }^{186,187}$ This issue was further highlighted by the first report of tumor formation from nonmarrow-derived stem/progenitors involving the therapeutic use of human neural stem cells to treat a young patient with inherited ataxia telangiectasia. ${ }^{188}$ In this case, the quality of stem cells was not reported, raising concerns of proper quality controls as well as raising an important issue about the age of the patient at the time of therapy. In fact, the authors of that report, who did not perform the therapy, caution the use of any progenitors or stem cells in a young environment which alone may drive oncogenesis in otherwise stable cells. This is also consistent with the last decade of human fetal neural stem cell therapy in older adults for Parkinson's disease, where tumor formation was not demonstrated. Or in the only reported study involving cells derived from a human pluripotent stem cell source. In this clinical study (performed by Layton Bioscience, Inc, Sunnyvale, CA), human ECCs were used to produce postmitotic neurons to treat stroke patients. After almost a decade of follow-up with multiple older patients there are still no reports of tumor formation. ${ }^{189-192}$

Future directions to eliminate possible stem cell-derived tumor formation have been proposed. ${ }^{47}$ These include genetic controls and cell targeting to selectively eliminate tumor forming stem cells after transplantation. Although experimental animal models and clinical trials in cancer gene therapy provide support for the utility of these strategies the need in the future will be to test these strategies in pluripotent stem cell derived transplants.

\section{Theoretical considerations}

Not only does the study of pluripotent stem cell derivation provide a potential source for patient-derived stem cell sources, but they also provide an excellent experimental model for regenerative medicine. Specifically, processes involved in cellular programming can be elucidated that can then be applied to other adult tissues. For instance, studying the process of derivation of iPSCs and EGCs from their differentiated predecessors can provide critical information regarding pathways involved in dedifferentiation. While iPSCs provide hope for reprogramming adult cells for therapeutic uses, they also stress the necessity in finding mechanisms regulating pluripotency and avoiding those associated with oncogenesis. For this purpose, the factors regulating cellular reprogramming of lineage-restricted cells 
like that seen in PGCs and adult germ cells during their derivation into pluripotent stem cells may be helpful.

\section{Acknowledgments}

We like to thank Fei Fei Liu and Marc Hiller for their assistance in cell culture and photography.

\section{Disclosures}

The authors have no conflicts of interest that are directly relevant to the content of this review.

\section{References}

1. Stevens LC. Development of resistance to teratocarcinogenesis by primordial germ cells in mice. J Natl Cancer Inst. 1966;37(6): 859-867.

2. Andrews PW. Teratocarcinomas and human embryology: pluripotent human EC cell lines. Review article. Apmis. 1998;106(1):158-167.

3. Stevens LC. Origin of testicular teratomas from primordial germ cells in mice. J Natl Cancer Inst. 1967;38(4):549-552.

4. Yu J, Thomson JA. Pluripotent stem cell lines. Genes Dev. 2008;22(15):1987-1997.

5. Eguizabal C, Shovlin TC, Durcova-Hills G, Surani A, McLaren A. Generation of primordial germ cells from pluripotent stem cells. Differentiation. 2009;78(2-3):116-123.

6. Yu Z, Ji P, Cao J, et al. Dazl promotes germ cell differentiation from embryonic stem cells. J Mol Cell Biol. 2009;1(2):93-103.

7. Haston KM, Tung JY, Reijo Pera RA. Dazl functions in maintenance of pluripotency and genetic and epigenetic programs of differentiation in mouse primordial germ cells in vivo and in vitro. PLoS One. 2009; 4(5):e5654.

8. Geijsen N, Horoschak M, Kim K, Gribnau J, Eggan K, Daley GQ. Derivation of embryonic germ cells and male gametes from embryonic stem cells. Nature. 2004;427(6970):148-154.

9. Hubner K, Fuhrmann G, Christenson LK, et al. Derivation of oocytes from mouse embryonic stem cells. Science. 2003;300(5623):1251-1256.

10. Nayernia K, Nolte J, Michelmann HW, et al. In vitro-differentiated embryonic stem cells give rise to male gametes that can generate offspring mice. Dev Cell. 2006;11(1):125-132.

11. Toyooka Y, Tsunekawa N, Akasu R, Noce T. Embryonic stem cells can form germ cells in vitro. Proc Natl Acad Sci USA. 2003;100(20): $11457-11462$.

12. Lacham-Kaplan O, Chy H, Trounson A. Testicular cell conditioned medium supports differentiation of embryonic stem cells into ovarian structures containing oocytes. Stem Cells. 2006;24(2):266-273.

13. Kerkis A, Fonseca SA, Serafim RC, et al. In vitro differentiation of male mouse embryonic stem cells into both presumptive sperm cells and oocytes. Cloning Stem Cells. 2007;9(4):535-548.

14. Clark AT, Bodnar MS, Fox M, et al. Spontaneous differentiation of germ cells from human embryonic stem cells In vitro. Hum Mol Genet. 2004;13(7):727-739.

15. Aflatoonian B, Moore H. Human primordial germ cells and embryonic germ cells, and their use in cell therapy. Curr Opin Biotechnol. 2005;16(5):530-535.

16. Kee K, Gonsalves JM, Clark AT, Pera RA. Bone morphogenetic proteins induce germ cell differentiation from human embryonic stem cells. Stem Cells Dev. 2006;15(6):831-837.

17. Tilgner K, Atkinson SP, Golebiewska A, Stojkovic M, Lako M, Armstrong L. Isolation of primordial germ cells from differentiating human embryonic stem cells. Stem Cells. 2008;26(12):3075-3085.

18. Park TS, Galic Z, Conway AE, et al. Derivation of primordial germ cells from human embryonic and induced pluripotent stem cells is significantly improved by coculture with human fetal gonadal cells. Stem Cells. 2009;27(4):783-795.
19. West FD, Machacek DW, Boyd NL, Pandiyan K, Robbins KR, Stice SL. Enrichment and differentiation of human germ-like cells mediated by feeder cells and basic fibroblast growth factor signaling. Stem Cells. 2008;26(11):2768-2776.

20. Bucay N, Yebra M, Cirulli V, et al. A novel approach for the derivation of putative primordial germ cells and sertoli cells from human embryonic stem cells. Stem Cells. 2009;27(1):68-77.

21. Zhao XY, Li W, Lv Z, et al. iPS cells produce viable mice through tetraploid complementation. Nature. 2009;461(7260):86-90.

22. Nagy A, Gocza E, Diaz EM, et al. Embryonic stem cells alone are able to support fetal development in the mouse. Development. 1990;110(3): 815-821.

23. Thomson JA. Embryonic stem cell lines derived from human blastocysts. [comment][erratum appears in Science 1998 4;282(5395):1827]. Science. 1998;282(5391):1145-1147.

24. Shamblott MJ, Axelman J, Wang S, et al. Derivation of pluripotent stem cells from cultured human primordial germ cells. Proc Natl Acad Sci U S A. 1998;95(23):13726-13731.

25. Evans MJ, Kaufman MH. Establishment in culture of pluripotential cells from mouse embryos. Nature. 1981;292(5819):154-156.

26. Martin GR. Isolation of a pluripotent cell line from early mouse embryos cultured in media conditioned by teratocarcinoma stem cells. Proc Natl Acad Sci U S A. 1981;78:7634-7638.

27. Smith AG. Embryo-derived stem cells: of mice and men. Annu Rev Cell Dev Biol. 2001;17:435-462.

28. Amit M, Itskovitz-Eldor J. Derivation and maintenance of human embryonic stem cells. In: Turksen T, editor. Methods in Molecular Biology, Volume 331: Human Embryonic Stem Cell Protocols. New York: Humana Press; 2006. p. 43-53.

29. Sullivan S, Cowan CA, Eggan K, editors. Human Embryonic Stem Cells: The Practical Handbook. West Sussex: John Wiley and Sons, Ltd; 2007,

30. Klimanskaya I, Lanza R, editors. Methods in Enzymology, Volume 418 : Embryonic Stem Cells. San Diego: Academic Press; 2006.

31. Lerou PH, Yabuuchi A, Huo H, et al. Derivation, growth and applications of human embryonic stem cells from poor-quality in vitro fertilization embryos. Reproduction. 2004;128(3):259-267.

32. Lerou PH, Yabuuchi A, Huo H, et al. Derivation and maintenance of human embryonic stem cells from poor-quality in vitro fertilization embryos. Reprod Biomed Online. 2008;3(5):923-933.

33. Bavister B. Oxygen concentration and preimplantation development. Reprod Biomed Online. 2004;9(5):484-486.

34. Ezashi T, Das P, Roberts RM. Low O2 tensions and the prevention of differentiation of hES cells. Proc Natl Acad Sci U S A. 2005;102(13): 4783-4788.

35. Forsyth NR, Musio A, Vezzoni P, Simpson AH, Noble BS, McWhir J. Physiologic oxygen enhances human embryonic stem cell clonal recovery and reduces chromosomal abnormalities. Cloning Stem Cells. 2006;8(1):16-23.

36. Yoshida Y, Takahashi K, Okita K, Ichisaka T, Yamanaka S. Hypoxia enhances the generation of induced pluripotent stem cells. Cell Stem Cell. 2009;5(3):237-241.

37. Lerou PH, Yabuuchi A, Huo H, et al. Derivation and maintenance of human embryonic stem cells from poor-quality in vitro fertilization embryos. Nat Protoc. 2008;3(5):923-933.

38. Cowan CAV, Svetlakov AV, Polstianoy AM, et al. Derivation of a novel human embryonic stem-cell line under serum-free and feeder-free conditions. Dokl Biol Sci. 2004;350(13):1353-1356.

39. Ludwig TE, Bergendahl V, Levenstein ME, Yu J, Probasco MD, Thomson JA. Feeder-independent culture of human embryonic stem cells. Nat Methods. 2006;3(8):637-646.

40. Ludwig TE, Levenstein ME, Jones JM, et al. Derivation of human embryonic stem cells in defined conditions. Nat Biotechnol. 2006;24(2):185-187.

41. Kim C, Amano T, Park J, Carter MG, Tian X, Yang X. Improvement of embryonic stem cell line derivation efficiency with novel medium, glucose concentration, and epigenetic modifications. Cloning Stem Cells. 2009;11(1):89-100. 
42. Tsuji-Takayama K, Inoue T, Ijiri Y, et al. Demethylating agent, 5-azacytidine, reverses differentiation of embryonic stem cells. Biochem Biophys Res Commun. 2004;323(1):86-90.

43. Lee JH, Hart SR, Skalnik DG. Histone deacetylase activity is required for embryonic stem cell differentiation. Genesis. 2004;38(1):32-38.

44. Feng B, Ng JH, Heng JC, Ng HH. Molecules that promote or enhance reprogramming of somatic cells to induced pluripotent stem cells. Cell Stem Cell. 2009;4(4):301-312.

45. Lee H, Park J, Forget BG, Gaines P. Induced pluripotent stem cells in regenerative medicine: an argument for continued research on human embryonic stem cells. Regen Med. 2009;4(5):759-769.

46. Amabile G, Meissner A. Induced pluripotent stem cells: current progress and potential for regenerative medicine. Trends $\mathrm{Mol} \mathrm{Med.}$ 2009;15(2):59-68.

47. Kiuru M, Boyer JL, O'Connor TP, Crystal RG. Genetic control of wayward pluripotent stem cells and their progeny after transplantation. Cell Stem Cell. 2009;4(4):289-300.

48. Feng B, Jiang J, Kraus P, et al. Reprogramming of fibroblasts into induced pluripotent stem cells with orphan nuclear receptor Esrrb. Nat Cell Biol. 2009;11(2):197-203.

49. Huangfu D, Osafune K, Maehr R, et al. Induction of pluripotent stem cells from primary human fibroblasts with only Oct4 and Sox2. Nat Biotechnol. 2008;26(11):1269-1275.

50. Mali P, Ye Z, Hommond HH, et al. Improved efficiency and pace of generating induced pluripotent stem cells from human adult and fetal fibroblasts. Stem Cells. 2008;26(8):1998-2005.

51. Stadtfeld M, Nagaya M, Utikal J, Weir G, Hochedlinger K. Induced pluripotent stem cells generated without viral integration. Science. 2008;322(5903):945-949.

52. Okita K, Nakagawa M, Hyenjong H, Ichisaka T, Yamanaka S. Generation of mouse induced pluripotent stem cells without viral vectors. Science. 2008;322(5903):949-953.

53. Kaji K, Norrby K, Paca A, Mileikovsky M, Mohseni P, Woltjen K. Virus-free induction of pluripotency and subsequent excision of reprogramming factors. Nature. 2009;458(7239):771-775.

54. Woltjen K, Michael IP, Mohseni P, et al. piggyBac transposition reprograms fibroblasts to induced pluripotent stem cells. Nature. 2009;458(7239):766-770.

55. Kim D, Kim CH, Moon JI, et al. Generation of human induced pluripotent stem cells by direct delivery of reprogramming proteins. Cell Stem Cell. 2009;4(6):472-476.

56. Mikkelsen TS, Hanna J, Zhang X, et al. Dissecting direct reprogramming through integrative genomic analysis. Nature. 2008;454(7200):49-55.

57. Shi Y, Do JT, Desponts C, Hahm HS, Scholer HR, Ding S. A combined chemical and genetic approach for the generation of induced pluripotent stem cells. Cell Stem Cell. 2008;2(6):525-528.

58. Marson A, Foreman R, Chevalier B, et al. Wnt signaling promotes reprogramming of somatic cells to pluripotency. Cell Stem Cell. 2008;3(2):132-135.

59. Silva J, Barrandon O, Nichols J, Kawaguchi J, Theunissen TW, Smith A. Promotion of reprogramming to ground state pluripotency by signal inhibition. PLoS Biol. 2008;6(10):e253.

60. Li W, Wei W, Zhu S, et al. Generation of rat and human induced pluripotent stem cells by combining genetic reprogramming and chemical inhibitors. Cell Stem Cell. 2009;4(1):16-19.

61. Palii SS, Van Emburgh BO, Sankpal UT, Brown KD, Robertson KD. DNA methylation inhibitor 5-Aza-2'-deoxycytidine induces reversible genome-wide DNA damage that is distinctly influenced by DNA methyltransferases 1 and 3B. Mol Cell Biol. 2008;28(2):752-771.

62. Brockes JP, Kumar A. Plasticity and reprogramming of differentiated cells in amphibian regeneration. Nat Rev Mol Cell Biol. 2002;3(8): 566-574.

63. Byrne JA, Nguyen HN, Reijo Pera RA. Enhanced generation of induced pluripotent stem cells from a subpopulation of human fibroblasts. PLoS One. 2009;4(9):e7118.

64. Yamanaka S. Elite and stochastic models for induced pluripotent stem cell generation. Nature. 2009;460(7251):49-52.
65. Hong H, Takahashi K, Ichisaka T, et al. Suppression of induced pluripotent stem cell generation by the p53-p21 pathway. Nature. 2009;460(7259):1132-1135.

66. Banito A, Rashid ST, Acosta JC, et al. Senescence impairs successful reprogramming to pluripotent stem cells. Genes Dev. 2009;23(18):2134-2139.

67. Eguchi G, Okada TS. Differentiation of lens tissue from the progeny of chick retinal pigment cells cultured in vitro: a demonstration of a switch of cell types in clonal cell culture. Proc Natl Acad Sci U S A. 1973;70(5):1495-1499.

68. Xie H, Ye M, Feng R, Graf T. Stepwise reprogramming of B cells into macrophages. Cell. 2004;117(5):663-676.

69. Zhou Q, Brown J, Kanarek A, Rajagopal J, Melton DA. In vivo reprogramming of adult pancreatic exocrine cells to beta-cells. Nature. 2008;455(7213):627-632.

70. Baker TG, Franchi LL. The fine structure of oogonia and oocytes in human ovaries. J Cell Sci. 1967;2(2):213-224.

71. Sun EL, Gondos B. Squash preparation studies of germ cells in human fetal testes. J Androl. 1984 Sep;5(5):334-338.

72. Makabe S, Naguro T, Motta PM. A new approach to the study of ovarian follicles by scanning electron microscopy and ODO maceration. Arch Histol Cytol. 1992;55 Suppl:183-190.

73. Heyn R, Makabe S, Motta PM. Ultrastructural dynamics of human testicular cords from 6 to 16 weeks of embryonic development. Study by transmission and high resolution scanning electron microscopy. Ital J Anat Embryol. 1998;103(4 Suppl 1):17-29.

74. Bendsen E, Byskov AG, Laursen SB, Larsen HP, Andersen CY, Westergaard LG. Number of germ cells and somatic cells in human fetal testes during the first weeks after sex differentiation. Hum Reprod. 2003;18(1):13-18.

75. Francavilla S, Cordeschi G, Properzi G, Concordia N, Cappa F, Pozzi V. Ultrastructure of fetal human gonad before sexual differentiation and during early testicular and ovarian development. J Submicrosc Cytol Pathol. 1990;22(3):389-400.

76. Witschi E. Embryology of the Ovary. In: Grady HG, Smith DE, editors. The Ovary. Baltimore: Williams and Wilkins; 1963:1-10.

77. Wartenberg H. Development of the early human ovary and role of the mesonephros in the differentiation of the cortex. Anat Embryol (Berl). $1982 ; 165(2): 253-280$.

78. Gondos B, Hobel CJ. Ultrastructure of germ cell development in the human fetal testis. Z Zellforsch Mikrosk Anat. 1971;119(1):1-20.

79. Labosky PA, Hogan BL. Mouse primordial germ cells: isolation and in vitro culture. Methods Mol Biol. 2008;461:187-199.

80. Dolci S, Pesce M, De Felici M. Combined action of stem cell factor, leukemia inhibitory factor, and cAMP on in vitro proliferation of mouse primordial germ cells. Mol Reprod Dev. 1993;35(2):134-139.

81. Hua J, Yu H, Liu S, et al. Derivation and characterization of human embryonic germ cells: serum-free culture and differentiation potential. Reprod Biomed Online. 2009;19(2):238-249.

82. Godin I, Wylie CC. TGF beta 1 inhibits proliferation and has a chemotropic effect on mouse primordial germ cells in culture. Development. 1991;113(4):1451-1457.

83. Matsui Y, Toksoz D, Nishikawa S, et al. Effect of Steel factor and leukaemia inhibitory factor on murine primordial germ cells in culture. Nature. 1991;353(6346):750-752.

84. Dolci S, Williams DE, Ernst MK, et al. Requirement for mast cell growth factor for primordial germ cell survival in culture. Nature. 1991;352(6338):809-811

85. Labosky PA, Barlow DP, Hogan BL. Embryonic germ cell lines and their derivation from mouse primordial germ cells. Ciba Found Symp. 1994;182:157-168.

86. Niwa H, Burdon T, Chambers I, Smith A. Self-renewal of pluripotent embryonic stem cells is mediated via activation of STAT3. Genes Dev. 1998;12(13):2048-2060.

87. Shamblott MJ, Kerr CL, Axelman J, et al. Derivation and Differentiation of Human Embryonic Germ Cells. In: Lanza R, Hogan B, Melton D, Pedersen R, Thomson J, West M, ed. Handbook of Stem Cells. Vol 1. New York: Elsevier Academic Press; 2004:459-469. 
88. De Felici M, Dolci S, Pesce M. Proliferation of mouse primordial germ cells in vitro: a key role for cAMP. Dev Biol. 1993;157(1):277-280.

89. Resnick JL, Bixler LS, Cheng L, Donovan PJ. Long-term proliferation of mouse primordial germ cells in culture. Nature. 1992;359(6395): $550-551$.

90. Matsui Y, Zsebo K, Hogan BL. Derivation of pluripotential embryonic stem cells from murine primordial germ cells in culture. Cell. 1992;70(5):841-847.

91. Guan K, Nayernia K, Maier LS, et al. Pluripotency of spermatogonial stem cells from adult mouse testis. Nature. 2006;440(7088): 1199-1203.

92. Izadyar F, Pau F, Marh J, et al. Generation of multipotent cell lines from a distinct population of male germ line stem cells. Reproduction. 2008;135(6):771-784.

93. Kanatsu-Shinohara M, Inoue K, Lee J, et al. Generation of pluripotent stem cells from neonatal mouse testis. Cell. 2004;119(7): 1001-1012.

94. Conrad S, Renninger M, Hennenlotter J, et al. Generation of pluripotent stem cells from adult human testis. Nature. 2008;456(7220): 344-349.

95. Kossack N, Meneses J, Shefi S, et al. Isolation and characterization of pluripotent human spermatogonial stem cell-derived cells. Stem Cells. 2009;27(1):138-149.

96. Ko K, Tapia N, Wu G, et al. Induction of pluripotency in adult unipotent germline stem cells. Cell Stem Cell. 2009;5(1):87-96.

97. Kossack N, Meneses J, Shefi S, et al. Isolation and characterization of pluripotent human spermatogonial stem cell-derived cells. Stem Cells. 2009;27(1):138-149.

98. Dym M, He Z, Jiang J, Pant D, Kokkinaki M. Spermatogonial stem cells: unlimited potential. Reprod Fertil Dev. 2009;21(1):15-21.

99. Oatley JM, Brinster RL. Spermatogonial stem cells. Methods Enzymol. 2006;419:259-282.

100. Kanatsu-Shinohara M, Takehashi M, Shinohara T. Brief history, pitfalls, and prospects of mammalian spermatogonial stem cell research Cold Spring Harb Symp Quant Biol. 2008;73:1 7-23.

101. Rougier N, Werb Z. Minireview: Parthenogenesis in mammals. Mol Reprod Dev. 2001;59(4):468-474.

102. Revazova ES, Turovets NA, Kochetkova OD, et al. Patient-specific stem cell lines derived from human parthenogenetic blastocysts. Cloning Stem Cells. 2007;9(3):432-449.

103. Cibelli JB, Cunniff K, Vrana KE. Embryonic stem cells from parthenotes. Methods Enzymol. 2006;418:117-135.

104. Surani MA, Barton SC, Norris ML. Development of reconstituted mouse eggs suggests imprinting of the genome during gametogenesis. Nature. 1984;308(5959):548-550.

105. McGrath J, Solter D. Inability of mouse blastomere nuclei transferred to enucleated zygotes to support development in vitro. Science. 1984;226(4680):1317-1319.

106. Kono T, Obata $Y, W u$ Q, et al. Birth of parthenogenetic mice that can develop to adulthood. Nature. 2004;428 \{6985):860-864.

107. Wu Q, Kumagai T, Kawahara M, et al. Regulated expression of two sets of paternally imprinted genes is necessary for mouse parthenogenetic development to term. Reproduction. 2006;131(3): 481-488.

108. Strain L, Warner JP, Johnston T, Bonthron DT. A human parthenogenetic chimaera. Nat Genet. 1995;11(2):164-169.

109. Revazova ES, Turovets NA, Kochetkova OD, et al. HLA Homozygous Stem Cell Lines Derived from Human Parthenogenetic Blastocysts. Cloning Stem Cells. 2008;10(1):11-24.

110. Hao J, Zhu W, Sheng C, Yu Y, Zhou Q. Human parthenogenetic embryonic stem cells: one potential resource for cell therapy. Sci China C Life Sci. 2009;52(7):599-602.

111. Allen ND, Barton SC, Hilton K, Norris ML, Surani MA. A functional analysis of imprinting in parthenogenetic embryonic stem cells. Development. 1994;120(6):1473-1482.

112. Kim K, Lerou P, Yabuuchi A, et al. Histocompatible embryonic stem cells by parthenogenesis. Science. 2007;315(5811):482-486.
113. Thomson JA, Solter D. The developmental fate of androgenetic, parthenogenetic, and gynogenetic cells in chimeric gastrulating mouse embryos. Genes Dev. 1988;2(10):1344-1351.

114. Mai Q, Yu Y, Li T, et al. Derivation of human embryonic stem cell lines from parthenogenetic blastocysts. Cell Res. 2007;17(12): 1008-1019.

115. Lin G, OuYang Q, Zhou X, et al. A highly homozygous and parthenogenetic human embryonic stem cell line derived from a onepronuclear oocyte following in vitro fertilization procedure. Cell Res. 2007;17(12):999-1007.

116. Hwang WS, Roh SI, Lee BC, et al. Patient-specific embryonic stem cells derived from human SCNT blastocysts. Science. 2005;308(5729): 1777-1783.

117. Kim K, Ng K, Rugg-Gunn PJ, et al. Recombination signatures distinguish embryonic stem cells derived by parthenogenesis and somatic cell nuclear transfer. Cell Stem Cell. 2007;1(3):346-352.

118. De Sousa PA, Gardner J, Sneddon S, et al. Clinically failed eggs as a source of normal human embryo stem cells. Stem Cell Res. 2009;2(3):188-197.

119. Lin H, Lei J, Wininger D, et al. Multilineage potential of homozygous stem cells derived from metaphase II oocytes. Stem Cells. 2003;21(2):152-161

120. Revazova ES, Turovets NA, Kochetkova OD, et al. HLA homozygous stem cell lines derived from human parthenogenetic blastocysts. Cloning Stem Cells. 2008;10(1):11-24.

121. Suss-Toby E, Gerecht-Nir S, Amit M, Manor D, Itskovitz-Eldor J. Derivation of a diploid human embryonic stem cell line from a mononuclear zygote. Hum Reprod. 2004;19(3):670-675.

122. McElroy SL, Kee K, Tran N, Menses J, Giudice LC, Reijo Pera RA. Developmental competence of immature and failed/abnormally fertilized human oocytes in nuclear transfer. Reprod Biomed Online. 2008;16(5):684-693

123. Xing F, Fang Z, Qin B, Li Y, Hou J, Chen X. Parthenogenetic embryonic stem cells derived from cryopreserved newborn mouse ovaries: a new approach to autologous stem cell therapy. Fertil Steril. 2009;91(4):1238-1244.

124. de Fried EP, Ross P, Zang G, et al. Human parthenogenetic blastocysts derived from noninseminated cryopreserved human oocytes. Fertil Steril. 2008;89(4):943-947.

125. Muller R, Lengerke C. Patient-specific pluripotent stem cells: promises and challenges. Nat Rev Endocrinol. 2009;5(4):195-203.

126. Eckardt S, Leu NA, Bradley HL, Kato H, Bunting KD, McLaughlin KJ. Hematopoietic reconstitution with androgenetic and gynogenetic stem cells. Genes Dev. 2007;21(4):409-419.

127. Koh CJ, Delo DM, Lee JW, et al. Parthenogenesis-derived multipotent stem cells adapted for tissue engineering applications. Methods. 2009;47(2):90-97.

128. Sanchez-Pernaute R, Lee H, Patterson M, et al. Parthenogenetic dopamine neurons from primate embryonic stem cells restore function in experimental Parkinson's disease. Brain. 2008;131(Pt 8): 2127-2139.

129. Bongso A, Fong CY, Gauthaman K. Taking stem cells to the clinic: Major challenges. J Cell Biochem. 2008;105(6):1352-1360.

130. Lo B, Garan N. Historical perspective and evolving concerns for human research. Cancer Treat Res. 2007;132:1-10.

131. Chaerkady R, Kerr CL, Marimuthu A, et al. Temporal analysis of neural differentiation using quantitative proteomics (dagger). J Proteome Res. 2009;8(3):1315-1326.

132. Aasen T, Raya A, Barrero MJ, et al. Efficient and rapid generation of induced pluripotent stem cells from human keratinocytes. Nat Biotechnol. 2008;26(11):1276-1284.

133. Ali SH, DeCaprio JA. Cellular transformation by SV40 large T antigen: interaction with host proteins. Semin Cancer Biol. 2001;11(1): $15-23$.

134. Kerr DA, Llado J, Shamblott MJ, et al. Human embryonic germ cell derivatives facilitate motor recovery of rats with diffuse motor neuron injury. J Neurosci. 2003;23(12):5131-5140. 
135. Mueller D, Shamblott MJ, Fox HE, Gearhart JD, Martin LJ. Transplanted human embryonic germ cell-derived neural stem cells replace neurons and oligodendrocytes in the forebrain of neonatal mice with excitotoxic brain damage. J Neurosci Res. 2005;82(5):592-608.

136. Frimberger D, Morales N, Shamblott M, Gearhart JD, Gearhart JP, Lakshmanan Y. Human embryoid body-derived stem cells in bladder regeneration using rodent model. Urology. 2005;65(4): 827-832.

137. Furth ME, Atala A. Stem cell sources to treat diabetes. J Cell Biochem. 2009;106(4):507-511.

138. Lindvall O, Kokaia Z. Prospects of stem cell therapy for replacing dopamine neurons in Parkinson's disease. Trends Pharmacol Sci. 2009;30(5):260-267.

139. Karussis D, Kassis I. The potential use of stem cells in multiple sclerosis: an overview of the preclinical experience. Clin Neurol Neurosurg. 2008;110(9):889-896.

140. Hwang NS, Varghese S, Lee HJ, et al. In vivo commitment and functional tissue regeneration using human embryonic stem cell-derived mesenchymal cells. Proc Natl Acad Sci U S A. 2008;105(52):20641-20646.

141. Hwang NS, Elisseeff J. Application of stem cells for articular cartilage regeneration. J Knee Surg. 2009;22(1):60-71.

142. Kroon E, Martinson LA, Kadoya K, et al. Pancreatic endoderm derived from human embryonic stem cells generates glucose-responsive insulin-secreting cells in vivo. Nat Biotechnol. 2008;26(4):443-452.

143. Kehat I, Khimovich L, Caspi O, et al. Electromechanical integration of cardiomyocytes derived from human embryonic stem cells. Nat Biotechnol. 2004;22(10):1282-1289.

144. Laflamme MA, Gold J, Xu C, et al. Formation of human myocardium in the rat heart from human embryonic stem cells. Am J Pathol. 2005;167(3):663-671.

145. Xue T, Cho HC, Akar FG, et al. Functional integration of electrically active cardiac derivatives from genetically engineered human embryonic stem cells with quiescent recipient ventricular cardiomyocytes: insights into the development of cell-based pacemakers. Circulation. 2005;111(1):11-20.

146. Leor J, Gerecht S, Cohen S, et al. Human embryonic stem cell transplantation to repair the infarcted myocardium. Heart. 2007;93(10): 1278-1284.

147. Ben-Hur T, Idelson M, Khaner H, et al. Transplantation of human embryonic stem cell-derived neural progenitors improves behavioral deficit in Parkinsonian rats. Stem Cells. 2004;22(7): 1246-1255.

148. Roy NS, Cleren C, Singh SK, Yang L, Beal MF, Goldman SA. Functional engraftment of human ES cell-derived dopaminergic neurons enriched by coculture with telomerase-immortalized midbrain astrocytes. Nat Med. 2006;12(11):1259-1268.

149. Liu S, Qu Y, Stewart TJ, et al. Embryonic stem cells differentiate into oligodendrocytes and myelinate in culture and after spinal cord transplantation. Proc Natl Acad Sci U S A. 2000;97(11): 6126-6131.

150. Keirstead HS, Nistor G, Bernal G, et al. Human embryonic stem cell-derived oligodendrocyte progenitor cell transplants remyelinate and restore locomotion after spinal cord injury. J Neurosci. 2005;25(19):4694-4705.

151. Faulkner J, Keirstead HS. Human embryonic stem cell-derived oligodendrocyte progenitors for the treatment of spinal cord injury. Transpl Immunol. 2005;15(2):131-142.

152. Cloutier F, Siegenthaler MM, Nistor G, Keirstead HS. Transplantation of human embryonic stem cell-derived oligodendrocyte progenitors into rat spinal cord injuries does not cause harm. Regen Med. 2006;1(4):469-479.

153. Daadi MM, Maag AL, Steinberg GK. Adherent self-renewable human embryonic stem cell-derived neural stem cell line: functional engraftment in experimental stroke model. PLoS One. 2008;3(2):e1644.

154. Daadi MM, Lee SH, Arac A, et al. Functional Engraftment of the Medial Ganglionic Eminence Cells in Experimental Stroke Model. Cell Transplant. 2009;18(7):815-826.
155. Hicks AU, Lappalainen RS, Narkilahti S, et al. Transplantation of human embryonic stem cell-derived neural precursor cells and enriched environment after cortical stroke in rats: cell survival and functional recovery. Eur J Neurosci. 2009;29(3):562-574.

156. Oyamada N, Itoh $\mathrm{H}$, Sone $\mathrm{M}$, et al. Transplantation of vascular cells derived from human embryonic stem cells contributes to vascular regeneration after stroke in mice. J Transl Med. 2008;6:54.

157. Soto-Gutierrez A, Kobayashi N, Rivas-Carrillo JD, et al. Reversal of mouse hepatic failure using an implanted liver-assist device containing ES cell-derived hepatocytes. Nat Biotechnol. 2006;24(11):1412-1419.

158. Vugler A, Carr AJ, Lawrence J, et al. Elucidating the phenomenon of HESC-derived RPE: anatomy of cell genesis, expansion and retinal transplantation. Exp Neurol. 2008;214(2):347-361.

159. Nistor GI, Totoiu MO, Haque N, Carpenter MK, Keirstead HS. Human embryonic stem cells differentiate into oligodendrocytes in high purity and myelinate after spinal cord transplantation. Glia. 2005;49(3):385-396.

160. Aharonowiz M, Einstein O, Fainstein N, et al. Neuroprotective effect of transplanted human embryonic stem cell-derived neural precursors in an animal model of multiple sclerosis. PLoS One. 2008; 3(9):e3145.

161. Couzin J. Biotechnology. Celebration and concern over US trial of embryonic stem cells. Science. 2009;323(5914):568.

162. Trounson A. New perspectives in human stem cell therapeutic research. BMC Med. 2009; 7:29.

163. Wernig M, Zhao JP, Pruszak J, et al. Neurons derived from reprogrammed fibroblasts functionally integrate into the fetal brain and improve symptoms of rats with Parkinson's disease. Proc Natl Acad Sci US A. 2008;105(15):5856-5861.

164. Nelson TJ, Martinez-Fernandez A, Yamada S, Perez-Terzic C, Ikeda Y, Terzic A. Repair of acute myocardial infarction by human stemness factors induced pluripotent stem cells. Circulation. 2009;120(5): 408-416.

165. Ebert AD, Yu J, Rose FF Jr, et al. Induced pluripotent stem cells from a spinal muscular atrophy patient. Nature. 2009;457(7227): 277-280

166. Dimos JT, Rodolfa KT, Niakan KK, et al. Induced pluripotent stem cells generated from patients with ALS can be differentiated into motor neurons. Science. 2008;321(5893):1218-1221.

167. Lee G, Papapetrou EP, Kim H, et al. Modelling pathogenesis and treatment of familial dysautonomia using patient-specific iPSCs. Nature. 2009;461(7262:402-406.

168. Maehr R, Chen S, Snitow M, et al. Generation of pluripotent stem cells from patients with type 1 diabetes. Proc Natl Acad Sci U S A. 2009;106:15523-15524.

169. Hanna J, Wernig M, Markoulaki S, et al. Treatment of sickle cell anemia mouse model with iPS cells generated from autologous skin. Science. 2007;318(5858):1920-1923.

170. Wang Y, Jiang Y, Liu S, Sun X, Gao S. Generation of induced pluripotent stem cells from human beta-thalassemia fibroblast cells. Cell Res. 2009;19(9):1120-1123.

171. Condic ML, Rao M. Regulatory issues for personalized pluripotent cells. Stem Cells. 2008;26(11):2753-2758.

172. Faden RR, Dawson L, Bateman-House AS, et al. Public stem cell banks: considerations of justice in stem cell research and therapy. Hastings Cent Rep. 2003;33(6):13-27.

173. Nakajima F, Tokunaga K, Nakatsuji N. Human leukocyte antigen matching estimations in a hypothetical bank of human embryonic stem cell lines in the Japanese population for use in cell transplantation therapy. Stem Cells. 2007;25(4):983-985.

174. Taylor CJ, Bolton EM, Pocock S, Sharples LD, Pedersen RA, Bradley JA. Banking on human embryonic stem cells: estimating the number of donor cell lines needed for HLA matching. Lancet. 2005;366(9502):2019-2025.

175. Strulovici Y, Leopold PL, O’Connor TP, Pergolizzi RG, Crystal RG. Human embryonic stem cells and gene therapy. Mol Ther. 2007;15(5): $850-866$. 
176. Harrison NJ, Baker D, Andrews PW. Culture adaptation of embryonic stem cells echoes germ cell malignancy. Int J Androl. 2007;30(4): 275-281.

177. Draper JS, Smith K, Gokhale P, et al. Recurrent gain of chromosomes $17 \mathrm{q}$ and 12 in cultured human embryonic stem cells. Nat Biotechnol. 2004;22(1):53-54.

178. Blum B, Benvenisty N. The tumorigenicity of human embryonic stem cells. Adv Cancer Res. 2008;100:133-158.

179. Spits C, Mateizel I, Geens M, et al. Recurrent chromosomal abnormalities in human embryonic stem cells. Nat Biotechnol. 2008;26(12):1361-1363.

180. Greaves MF. Cord blood donor cell leukemia in recipients. Leukemia. 2006;20(9):1633-1634.

181. Barozzi P, Luppi M, Facchetti F, et al. Post-transplant Kaposi sarcoma originates from the seeding of donor-derived progenitors. Nat Med. 2003;9(5):554-561.

182. Avital I, Moreira AL, Klimstra DS, et al. Donor-derived human bone marrow cells contribute to solid organ cancers developing after bone marrow transplantation. Stem Cells. 2007;25(11):2903-2909.

183. Golfinopoulos V, Pentheroudakis G, Kamakari S, Metaxa-Mariatou V, Pavlidis N. Donor-derived breast cancer in a bone marrow transplantation recipient. Breast Cancer Res Treat. 2009;113(2):211-213.

184. Dubernard G, Aractingi S, Oster M, et al. Breast cancer stroma frequently recruits fetal derived cells during pregnancy. Breast Cancer Res. 2008;10(1):R14.

185. Roorda BD, ter Elst A, Kamps WA, de Bont ES. Bone marrow-derived cells and tumor growth: contribution of bone marrow-derived cells to tumor micro-environments with special focus on mesenchymal stem cells. Crit Rev Oncol Hematol. 2009;69(3):187-198.
186. Johnson KL, Bianchi DW. Fetal cells in maternal tissue following pregnancy: what are the consequences? Hum Reprod Update. 2004;10(6):497-502.

187. Cha D, Khosrotehrani K, Kim Y, Stroh H, Bianchi DW, Johnson KL. Cervical cancer and microchimerism. Obstet Gynecol. 2003;102(4): 774-781.

188. Amariglio N, Hirshberg A, Scheithauer BW, et al. Donor-derived brain tumor following neural stem cell transplantation in an ataxia telangiectasia patient. PLoS Med. 2009;6(2):e1000029.

189. Stilley CS, Ryan CM, Kondziolka D, Bender A, DeCesare S, Wechsler L. Changes in cognitive function after neuronal cell transplantation for basal ganglia stroke. Neurology. 2004;63(7):1320 1322.

190. Watson DJ, Longhi L, Lee EB, et al. Genetically modified NT2N human neuronal cells mediate long-term gene expression as CNS grafts in vivo and improve functional cognitive outcome following experimental traumatic brain injury. J Neuropathol Exp Neurol. 2003;62(4):368-380.

191. Kondziolka D, Wechsler L, Goldstein S, et al. Transplantation of cultured human neuronal cells for patients with stroke. Neurology. 2000;55(4):565-569.

192. Wechsler LR. Clinical trials of stroke therapy: which cells, which patients? Stroke. 2009;40(3 Suppl):S149-S151.
Stem Cells and Cloning: Advances and Applications

\section{Publish your work in this journal}

Stem Cells and Cloning: Advances and Applications is an international, peer-reviewed, open access journal. Areas of interest in stem cell research include: Embryonic cell stems; Adult stem cells; Blastocysts; Cordblood stem cells; Stem cell transformation and culture; Therapeutic cloning; Umbilical cord blood and bone marrow cells; Laboratory,

\section{Dovepress}

animal and human therapeutic studies; Philosophical and ethical issues related to stem cell research. This journal is indexed on CAS. The manuscript management system is completely online and includes a quick and fair peer-review system. Visit http://www.dovepress.com/ testimonials.php to read real quotes from published authors. 